Original Article

\title{
HEALTH CARE FACILITIES FOR SENIOR CITIZENS IN SELECTED TERTIARY HOSPITALS DURING COVID-19 PANDEMIC
}

\author{
Sathi Binte Ali ${ }^{1}$, Mohammad Asraful Alam ${ }^{2}$
}

\begin{abstract}
Background: To assess the health care facilities provided for senior citizens in selected tertiary hospitals.

Methods: This descriptive type of cross-sectional study was carried out among service providers (doctors and nurses) and hospital administrators within the period of January to December 2020. A total of 305 respondents was selected purposively. Semi structured questionnaire and observational checklist was used to collect data. Data was collected by face to face interview and observation. Data was analyzed by using SPSS (Statistical Package for Social Science) software version 25 .

Results: Among participants, Administrator 2.6\%, Doctor 25.2\% and Nurse 72.1\%. Mean age of the respondents was $32.72 \pm 7.67$ years. Most of the respondents $90.8 \%$ working experience less than 10 years and their average monthly income was Tk. 35398.90 \pm 16509.12 . In DMCH separate geriatric ward present but in BSMMU geriatric ward absent. Rehabilitation center \& long-term care facilities for elderly patients, telemedicine service, separation facility for non COVID geriatric patients from COVID positive patients, free care facility for poor elderly patients, social welfare support facilities present in both hospitals. Separate bed facility in general wards, geriatric ICU and COVID ward absent, training facility on geriatric health absent in both hospitals. Majority of the respondents $97.0 \%$ take consent before any procedure, $89.6 \%$ service provider involve geriatric patients in decision making about their care and treatment, $56.6 \%$ respondents follow polypharmacy guideline. Opinion regarding utility service was average. Opinion regarding diagnostic facilities, essential drugs, sterilization facilities, of this hospital for senior citizens was moderately sufficient $50.5 \%, 60.6 \%$ and 59.3\% respectively and ambulance service insufficient 53.4\%. Among respondents $89.8 \%$ face barriers in providing geriatric health care. Opinion regarding the existing health care facilities for senior citizens of this hospitals insufficient 52.8\%. Regarding improvement of health care services $26.0 \%$ mentioned that training of doctor/ nurses followed by separate geriatric ward facilities for geriatric patients $20.8 \%$, increase the number of supporting staff $16.2 \%$, free health care facilities for poor elderly patients $11.8 \%$, training of supporting staffs $10.6 \%$, training for informal/family caregiver $7.4 \%$, separate bed for geriatric patient in general wards $6.4 \%$ and the rest others mentioned $0.7 \%$. Analysis found statistically significant association between national guideline follow for the treatment and care of older patients and their educational qualification (0.001), designation $(\mathrm{p}=0.001)$, polypharmacy guideline follows for the treatment and care of older patients and their designation, referral guideline follows for geriatric patients and their designation $(\mathrm{p}=0.001)$.
\end{abstract}

Conclusion: To provide quality healthcare service to the senior citizens of Bangladesh, geriatric health care should be given highest priority.

JOPSOM 2021; 40(1):51-58

https://doi.org/10.3329/jopsom.v40i1.56691

Keywords: Health, Care, Health care facilities, Senior citizens, Tertiary hospital, COVID-19, Service provider.

1. Sathi Binte Ali, Nursing Officer, Dhaka Medical College Hospital, Dhaka-1000.

2. Dr. Mohammad Asraful Alam, MBBS, MPH, Assistant Professor, Department of Public Health and Hospital Administration, NIPSOM, Mohakhali, Dhaka-1212.

Correspondence: Sathi Binte Ali, e-mail: sathi6667@gmail.com 


\section{INTRODUCTION}

Ageing is a normal biological phenomenon.1 People aged 60 and over are defined as the senior citizen. In Bangladesh, as per the provision of rule 8(1) of the National Policy on Older Persons 2013, Govt. has declared the citizen above 60 years are Senior citizen 1. Aging causes a functional deterioration, degradation of physical strength and hindrance to carry out one's normal functioning as one did before. Old age is neither a disease nor an individual problem; rather, it has become a worldwide challenge that must be addressed globally. "Later life" is unavoidable, inevitable, universal and excessively troublesome. No one can stop the process of ageing. 2

In Bangladesh due to improved quality of life the number of people over 60 years is increasing rapidly. This should be seen as an emerging challenge as the elderly will have special needs and require different care-giving services. Since Bangladesh does not have a social welfare system there will be competition for inadequate resources specially health and medical services. It is envisaged that due to more elderly population the demographic structure will undergo a slow change from the present pyramid structure. The growing trend towards the nuclear family or where children live abroad will put the elderly parents in a dilemma-the financial and social support that is essential for them has not yet emerged. The nutrition and health status of elderly people depend on adequate food safe water, proper sanitation facilities and maintaining hygienic standards. To provide special medical care for the elderly there is a need to establish WHO recommended Age-Friendly Primary Health Care centers and separate wards /units are to be set up in the hospitals. To reduce vulnerability of older women there is a need to distribute assets and properties according to the law. Our new generations have to be responsive, informed and attentive about their duties and responsibilities towards the elderly people. Taking proper care of the elderly is our ethical duty and responsibility. 3

Due to a fall in mortality rate, accompanied with fertility decline over the last few decades, the elderly population of Bangladesh is continuously increasing. According to 2011 censuses, the elderly populations in Bangladesh were 11.3 million. 1

Between 2015 and 2050, the proportion of the world's population over 60 years will nearly double from $12 \%$ to $22 \%$. By 2020, the number of people aged 60 years and older will outnumber children younger than 5 years. In 2050, $80 \%$ of older people will be living in low- and middle-income countries. The pace of population ageing is much faster than in the past. All countries face major challenges to ensure that their health and social systems are ready to make the most of this demographic shift. 4 Bangladesh needs to meet the challenges of both frequent disasters and rapidly growing older persons.

Coronavirus infection is a major threat to the global community. Bangladesh is densely populated country. High density of population makes Bangladesh more vulnerable to the spread of the virus compared to countries where population density is lower.

The COVID-19 virus infects people of all ages. However, evidence to date suggests that two groups of people are at a higher risk of getting severe COVID19 disease. These are older people; and those with underlying medical conditions. WHO emphasizes that all must protect themselves from COVID-19 in order to protect others. 5

We can help to ensure a healthy ageing and active later life. If policy response to focus on the provision of medical care and income security for older persons we can ensure healthy ageing. Which important but have been inadequate compared to the rate of ageing occurring now and projected to intensify in the coming decades. 1

\section{MATERIALS AND METHODS}

This descriptive type of cross-sectional study was carried out among service providers (doctors and nurses) and hospital administrators of Dhaka Medical College Hospital (DMCH) and Bangabandhu Sheikh Mujib Medical University (BSMMU) Hospital. Study period was January to December 2020. A total of 305 respondents was selected by convenient method of sampling. Semi structured questionnaire and observational checklist was used to collect data. Data was collected by face to face interview and observation. Data was analyzed by using SPSS (Statistical Package for Social Science) software version 25 .

\section{RESULTS}

Among the respondents, administrator $(\mathrm{n}=8,2.6 \%)$, doctor $(n=77,25.2 \%)$ and nurse $(n=220,72.1 \%)$. Highest percentage of the respondents were in the age group $24-33$ years $(n=211,69.2 \%)$, followed by $34-43$ years $(n=61,20.0 \%), 44-53$ years $(n=23,7.5 \%)$ and the rest $\geq 54$ years $(\mathrm{n}=10,3.3 \%)$. Male respondents $(\mathrm{n}=62$, $20.3 \%)$ and female respondents $(\mathrm{n}=243,79.7 \%)$. Most of the respondents in the religion group Islam $83.0 \%$ was followed by Hinduism 14.8\%, Christianism 2.0\% and the rest Buddhism $0.3 \%$ respondents. Respondents had B. Sc/ Diploma in nursing education 61.0\% followed by MBBS $21.3 \%$, post-graduation $17.4 \%$ and $\mathrm{PhD} 0.3 \%$. Most of the respondents $74.4 \%$ were married followed by single $25.2 \%$ and widowed/ 
widower was $0.3 \%$ respondents. most of the respondents live in nuclear family $(n=260,85.2 \%)$ and rest joint family $(n=45,14.8 \%)$. majority of the respondents were Senior Staff Nurse/ Assistant Nurse $(\mathrm{n}=220,72.1 \%)$, followed by Doctor (HMO, MO, IMO, EMO, Resident Doctor, Assistant Register) $(\mathrm{n}=74,24.3 \%)$, Director/ Assistant Director $(\mathrm{n}=4$, $1.3 \%)$, Nursing Superintendent/ Deputy Nursing Superintendent $(n=4,1.3 \%)$ and rest of the respondents $(n=3,1.0 \%)$ were Associate Professor/ Assistant Professor. Most of the respondents working experience $\leq 10$ years $(n=277,90.8 \%)$, followed by $(\mathrm{n}=17,5.6 \%)$ had working experience 11 years- 20 years and the rest $(n=11,3.6 \%)$ had working experience $\geq 21$ years. This table shows that most of the respondents average daily working hours 6-8 $(n=294,96.4 \%)$, followed by $(n=9,3.0 \%)$ had working hours $9-11$ and the rest $(n=2,0.7 \%)$ had average daily working hours $12-14$. The mean monthly income was Taka. 35398.90 \pm 16509.12 ranging from Taka 0$1,50,000$. Majority of the respondents $(n=234,76.7 \%)$ monthly income Taka 25,001-50,000, followed by $(\mathrm{n}=37,12.1 \%)$ had income Taka 0-25,000, $(\mathrm{n}=28$, $9.2 \%$ ) had monthly income Taka 50,000-75,000 and the rest $(n=6,2.0 \%)$ had monthly income Taka $\geq 75,001$.

Table 1: Socio-economic characteristics of the respondents

\begin{tabular}{|c|c|c|c|}
\hline \multicolumn{2}{|l|}{ Characteristics } & \multirow{2}{*}{\begin{tabular}{|l} 
Frequency \\
8
\end{tabular}} & \multirow{2}{*}{\begin{tabular}{|l|} 
Percent \\
2.6
\end{tabular}} \\
\hline \multirow{3}{*}{$\begin{array}{l}\text { Types of } \\
\text { participants }\end{array}$} & Administrator & & \\
\hline & Doctor & 77 & 25.2 \\
\hline & Nurse & 220 & 72.1 \\
\hline \multirow{4}{*}{ Age group (years) ${ }^{1}$} & $24-33$ & 211 & 69.2 \\
\hline & $34-43$ & 61 & 20.0 \\
\hline & $44-53$ & 23 & 7.5 \\
\hline & $>\geq 54$ & 10 & 3.3 \\
\hline \multirow{2}{*}{ Gender } & Male & 62 & 20.3 \\
\hline & Female & 243 & 79.7 \\
\hline \multirow{4}{*}{ Re Religion } & Islam & 253 & 83.0 \\
\hline & Hinduism & 45 & 14.8 \\
\hline & Christianism & 6 & 2.0 \\
\hline & Buddhism & 1 & 0.3 \\
\hline \multirow{4}{*}{ Educational status } & B.Sc/Diploma in Nursing & 186 & 61.0 \\
\hline & MBBS & 65 & 21.3 \\
\hline & Post-Graduation & 53 & 17.4 \\
\hline & $\mathrm{PhD}$ & 1 & 0.3 \\
\hline \multirow{3}{*}{ Marital Status } & Married & 227 & 74.4 \\
\hline & Single & 77 & 25.2 \\
\hline & Widowed/widower & 1 & 0.3 \\
\hline \multirow{2}{*}{ Family type } & Joint & 45 & 14.8 \\
\hline & Nuclear & 260 & 85.2 \\
\hline \multirow{4}{*}{ Designation } & SSN/ Assistant Nurse & 220 & 72.1 \\
\hline & Doctor & 74 & 24.3 \\
\hline & Director/Assistant Director & 4 & 1.3 \\
\hline & $\begin{array}{l}\text { Nursing Superintendent/Deputy } \\
\text { Nursing Superintendent }\end{array}$ & 4 & 1.3 \\
\hline
\end{tabular}




\begin{tabular}{|c|c|c|c|}
\hline & $\begin{array}{l}\text { Associate Professor/Assistant } \\
\text { Professor }\end{array}$ & 3 & 1.0 \\
\hline \multirow{3}{*}{$\begin{array}{l}\text { Working } \\
\text { experience }\end{array}$} & $\leq 10$ years & 277 & 90.8 \\
\hline & 11years -20 years & 17 & 5.6 \\
\hline & $\geq 21$ years & 11 & 3.6 \\
\hline \multirow{3}{*}{ Working hour } & $6-8$ & 294 & 96.4 \\
\hline & $9-11$ & 9 & 3.0 \\
\hline & $12-14$ & 2 & 0.7 \\
\hline \multirow{4}{*}{$\begin{array}{l}\text { Monthly Income } \\
(\text { Taka) }\end{array}$} & $0-25,000$ & 37 & 12.1 \\
\hline & $25,001-50,000$ & 234 & 76.7 \\
\hline & $50,001-75,000$ & 28 & 9.2 \\
\hline & $\geq 75,001$ & 6 & 2.0 \\
\hline
\end{tabular}

Mean: $32.72( \pm 7.67)$

Mean: $35398.90( \pm 16509.12)$

Table 2: Distribution of the respondents by information on existing health care facilities for senior citizens

\begin{tabular}{|l|c|c|c|c|c|}
\hline \multirow{2}{*}{ Opinion } & \multicolumn{2}{|c|}{ Yes } & \multicolumn{2}{c|}{ No } & Total \\
\cline { 2 - 6 } & Frequency & Percentage & Frequency & Percentage & \\
\hline $\begin{array}{l}\text { Separate geriatric ward for senior } \\
\text { citizens }\end{array}$ & 5 & 62.5 & 3 & 37.5 & 8 \\
\hline Separate geriatric male ward & 5 & 62.5 & 3 & 37.5 & 8 \\
\hline Separate geriatric female ward & 5 & 62.5 & 3 & 37.5 & 8 \\
\hline $\begin{array}{l}\text { Separate bed facility for elderly } \\
\text { patients in general wards }\end{array}$ & 0 & 0.0 & 8 & 100.0 & 8 \\
\hline Long stay geriatric beds facility & 0 & 0.0 & 8 & 100.0 & 8 \\
\hline $\begin{array}{l}\text { Rehabilitation center \& long-term } \\
\text { care facilities for elderly patients }\end{array}$ & 8 & 100.0 & 0 & 0.0 & 8 \\
\hline Geriatric ICU & 0 & 0.0 & 8 & 100.0 & 8 \\
\hline $\begin{array}{l}\text { Separation facility for non COVID } \\
\text { geriatric patients from COVID } \\
\text { positive patients }\end{array}$ & 8 & 100.0 & 0 & 0.0 & 8 \\
\hline Separate geriatric COVID ward & 0 & 0.0 & 8 & 100.0 & 8 \\
\hline $\begin{array}{l}\text { Telemedicine service facility for } \\
\text { geriatric patient during COVID- 19 } \\
\text { pandemic }\end{array}$ & 8 & 100.0 & 0 & 0.0 & 8 \\
\hline $\begin{array}{l}\text { Free care facility for poor elderly } \\
\text { patients }\end{array}$ & 8 & 100.0 & 0 & 0.0 & 8 \\
\hline $\begin{array}{l}\text { Social welfare support facilities for } \\
\text { poor elderly patients }\end{array}$ & 8 & 100.0 & 0 & 0.0 & 8 \\
\hline Prayer facility for elderly patients & 8 & 100.0 & 0 & 0.0 & 8 \\
\hline $\begin{array}{l}\text { Recreational facilities for elderly } \\
\text { patients }\end{array}$ & 0 & 0.0 & 8 & 100.0 & 8 \\
\hline $\begin{array}{l}\text { Training facilities for health care } \\
\text { providers on geriatric health care }\end{array}$ & 0 & 0.0 & 8 & 100.0 & 8 \\
\hline $\begin{array}{l}\text { Counseling service and training } \\
\text { facilities on geriatric health care for } \\
\text { informal/ family caregivers }\end{array}$ & 0 & 0.0 & 8 & 100.0 & 8 \\
\hline $\begin{array}{l}\text { Infection prevention and control team } \\
\text { working in hospital }\end{array}$ & 8 & 100.0 & 0 & 0.0 & 8 \\
\hline
\end{tabular}


Table-3: Distribution of the respondents regarding utility services for senior citizens

\begin{tabular}{|l|l|c|c|}
\hline \multirow{4}{*}{ Opinion regarding Dietary service } & \multicolumn{1}{|c|}{ Opinion } & Frequency & Percentage \\
\cline { 2 - 4 } & Very good & 14 & 4.6 \\
\cline { 2 - 4 } & Good & 72 & 23.6 \\
\cline { 2 - 4 } & Average & 194 & 63.6 \\
\cline { 2 - 4 } & Bad & 25 & 8.2 \\
\hline \multirow{4}{*}{ Opinion regarding Laundry and linen service } & Very good & 7 & 2.3 \\
\cline { 2 - 4 } & Good & 68 & 22.3 \\
\cline { 2 - 4 } & Average & 128 & 42.0 \\
\cline { 2 - 4 } & Bad & 102 & 33.4 \\
\hline \multirow{4}{*}{$\begin{array}{l}\text { Opinion regarding Security service } \\
\text { facilities of this hospital }\end{array}$} & Very good & 132 & 8.2 \\
\cline { 2 - 4 } & Good & 134 & 43.3 \\
\cline { 2 - 4 } & Average & 14 & 43.9 \\
\cline { 2 - 4 } & Bad & 118 & 4.6 \\
\hline \multirow{3}{*}{ Proper use of colour coded waste bin } & Sufficient & 136 & 38.7 \\
\cline { 2 - 4 } & Moderately sufficient & 4 & 44.6 \\
\cline { 2 - 4 } & Insufficient & 194 & 63.6 \\
\cline { 2 - 4 } & Not sure & 6 & 34.4 \\
\cline { 2 - 4 } & Yes & No & 2.0 \\
\cline { 2 - 4 } & Don't Know & & \\
\hline
\end{tabular}

Table 4: Distribution of the respondents regarding support services for senior citizens

\begin{tabular}{|c|c|c|c|}
\hline \multirow{5}{*}{ Opinion regarding Diagnostic facilities } & Opinion & Frequency & Percentage \\
\hline & Sufficient & 110 & 36.1 \\
\hline & Moderately sufficient & 154 & 50.5 \\
\hline & Insufficient & 38 & 12.5 \\
\hline & Don't know & 3 & 1.0 \\
\hline \multirow{4}{*}{ Opinion regarding Essential drugs } & Sufficient & 75 & 24.6 \\
\hline & Moderately sufficient & 183 & 60.0 \\
\hline & Insufficient & 43 & 14.1 \\
\hline & Don't know & 4 & 1.3 \\
\hline \multirow{4}{*}{ Opinion regarding Sterilization facilities } & Sufficient & 73 & 23.9 \\
\hline & Moderately sufficient & 181 & 59.3 \\
\hline & Insufficient & 51 & 16.7 \\
\hline & Don't know & 0 & 0.0 \\
\hline \multirow{4}{*}{ Opinion regarding Ambulance service } & Sufficient & 27 & 8.9 \\
\hline & Moderately sufficient & 76 & 24.9 \\
\hline & Insufficient & 163 & 53.4 \\
\hline & Don't know & 39 & 12.8 \\
\hline \multirow{4}{*}{$\begin{array}{l}\text { Opinion regarding cost of diagnostic test of } \\
\text { the hospital }\end{array}$} & Reasonable & 167 & 54.8 \\
\hline & Cheap & 66 & 21.6 \\
\hline & Costly & 51 & 16.7 \\
\hline & Don't know & 21 & 6.9 \\
\hline \multirow{4}{*}{$\begin{array}{l}\text { Opinion regarding infection prevention and } \\
\text { control }\end{array}$} & Very good & 13 & 4.3 \\
\hline & Good & 81 & 26.6 \\
\hline & Average & 183 & 60.0 \\
\hline & Bad & 28 & 9.2 \\
\hline Opinion regarding physiotherapy service & Very good & 21 & 6.9 \\
\hline
\end{tabular}




\begin{tabular}{|l|l|c|c|}
\hline \multirow{4}{*}{ Opinion regarding housekeeping service } & Good & 126 & 41.3 \\
\cline { 2 - 4 } & Average & 145 & 47.5 \\
\cline { 2 - 4 } & Bad & 13 & 4.3 \\
\hline & Very good & 16 & 5.2 \\
\cline { 2 - 4 } & Good & 69 & 22.6 \\
\cline { 2 - 4 } & Average & 169 & 55.4 \\
\cline { 2 - 4 } & Bad & 51 & 16.7 \\
\hline
\end{tabular}

Table 5: Observational Checklist for Care Facilities of Senior Citizens

\begin{tabular}{|c|c|c|c|c|c|c|c|c|c|}
\hline \multirow[b]{2}{*}{$\begin{array}{l}\text { Sl. } \\
\text { No }\end{array}$} & \multirow[b]{2}{*}{ Checklist } & \multicolumn{4}{|c|}{ DMCH } & \multicolumn{4}{|c|}{ BSMMU } \\
\hline & & 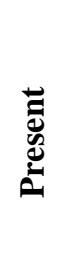 & 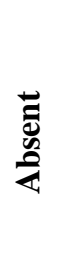 & 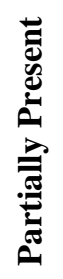 & 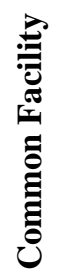 & 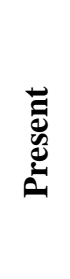 & 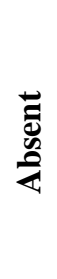 & 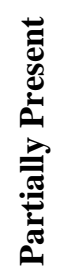 & 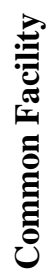 \\
\hline 1 & Entrance of the Hospital for Geriatric Patients & & & & $\sqrt{ }$ & & & & $\sqrt{ }$ \\
\hline 2 & Reception Facilities for Geriatric Patients & & $\sqrt{ }$ & & & & $\sqrt{ }$ & & \\
\hline 3 & Waiting Room Facilities for Geriatric Patients & & $\sqrt{ }$ & & & & $\sqrt{ }$ & & \\
\hline 4 & $\begin{array}{l}\text { Facilities for Geriatric Patients at Emergency } \\
\text { Department }\end{array}$ & & & & $\sqrt{ }$ & & & & $\sqrt{ }$ \\
\hline 5 & $\begin{array}{l}\text { Facilities for Geriatric Patient at Out Patient Department } \\
\text { (OPD) }\end{array}$ & & & & $\sqrt{ }$ & & & & $\sqrt{ }$ \\
\hline 6 & $\begin{array}{l}\text { Available Out Patient Department Services for Geriatric } \\
\text { Patients }\end{array}$ & & & & $\sqrt{ }$ & & & & $\sqrt{ }$ \\
\hline 7 & Facilities for Geriatric Patient at In Patient Department & $\sqrt{ }$ & & & & & $\sqrt{ }$ & & \\
\hline 8 & Operation Theater Facilities for Senior Citizens & & & & $\sqrt{ }$ & & & & $\sqrt{ }$ \\
\hline 9 & Separate Geriatric COVID Ward & & $\sqrt{ }$ & & & & $\sqrt{ }$ & & \\
\hline 10. & Geriatric ICU & & $\sqrt{ }$ & & & & $\sqrt{ }$ & & \\
\hline 11. & Utility Services for Senior Citizens & & & & $\sqrt{ }$ & & & & $\sqrt{ }$ \\
\hline 12. & Support Services for Senior Citizens & & & & $\sqrt{ }$ & & & & $\sqrt{ }$ \\
\hline
\end{tabular}

\section{DISCUSSION}

This descriptive type cross sectional study was conducted at Dhaka Medical College Hospital $(\mathrm{DMCH})$ and Bangabandhu Sheikh Mujib Medical University (BSMMU) Hospital from the period of January to December 2020. A total of 305 service provider were interviewed with semi structured questionnaire and checklist. Significant findings of the study after data analysis are discussed below-

Study respondents 305 service provider administrators $2.6 \%$, doctor $25.2 \%$ and nurse $72.1 \%$. Male respondents $20.3 \%$ and female respondents $79.7 \%$. Another study conducted in Bangladesh in management of geriatric health services in a specialized hospital where male respondent was $38.5 \%$ and $61.5 \%$ female 6 . Among 305 service provider lowest age was 24 and highest age 58 years. Majority of the respondents was in the age group 2433 years $69.2 \%$ and the lowest $3.3 \%$ in the age group $\geq 54$ years.

In this study majority of the respondents were in religion group Islam $83.0 \%$ and the lowest $0.3 \%$ in the religion Buddhism. Among service provider $74.4 \%$ respondents was married, $25.2 \%$ unmarried and the rest $0.3 \%$ was widowed/ widower and most of them $85.2 \%$ lives in nuclear family and $14.8 \%$ in joint family.

Study revealed that $61.0 \%$ respondent's educational qualification B. Sc/ diploma in nursing, MBBS 21.3\%, post- graduate $17.4 \%$ and $\mathrm{PhD} 0.3 \%$. which has similarity with this study conducted in Bangladesh 
where $34.6 \%$ was MBBS and post-graduation $23.1 \%$ 6.

Most of the respondents working experience $\leq 10$ years $(n=277,90.8 \%)$, followed by $(n=17,5.6 \%)$ had working experience 11 years- 20 years and the rest ( $\mathrm{n}=11,3.6 \%)$ had working experience $\geq 21$ years. Another study finding $46.1 \%$ respondents working experience in $1-5$ year, $30.8 \%$ in between $6-10$ years, $15.4 \%$ in $11-15$ years and the rest $7.7 \%$ respondents working experience more than 21 years 6 .

Majority of the respondents were Senior Staff Nurse/ Assistant Nurse ( $\mathrm{n}=220,72.1 \%)$, followed by Doctor $(\mathrm{n}=74,24.3 \%)$, Director/ Assistant Director $(\mathrm{n}=4$, 1.3\%), Nursing Superintendent/ Deputy Nursing Superintendent $(\mathrm{n}=4,1.3 \%)$ and rest of the respondents $(n=3,1.0 \%)$ were Associate Professor/ Assistant Professor. Study done by Himel revealed that doctor $23.1 \%$, general physician $34.6 \%$, specialist physician $23.1 \%$.

Study revealed that most of the respondents average daily working hours $6-8(\mathrm{n}=294,96.4 \%)$, followed by $(n=9,3.0 \%)$ had working hours $9-11$ and the rest $(n=2$, $0.7 \%$ ) had average daily working hours $12-14$.

Majority of the respondents $(n=234,76.7 \%)$ monthly income Taka 25,001-50,000, followed by $(\mathrm{n}=37$, $12.1 \%)$ had income Taka $0-25,000,(n=28,9.2 \%)$ had monthly income Taka 50,000-75,000 and the rest $(\mathrm{n}=6,2.0 \%)$ had monthly income Taka $\geq 75,001$.

Opinion regarding dietary service, laundry and linen service and security service: highest percentage $63.6 \%$ respondent regarded dietary service as average. $42.0 \%$ respondent regarded laundry and linen service as average and $43.9 \%$ respondent regarded security service as average which has similarity with another study. Where $57.7 \%$ respondent regarded laundry and linen service average, $26.9 \%$ response average security service (Himel, 2019).

In this study $50.5 \%$ respondent regarded diagnostic facilities as moderately sufficient, $60.0 \%$ respondent regarded essential drugs as moderately sufficient, $59.3 \%$ respondent regarded sterilization facilities as moderately sufficient and $53.4 \%$ respondent regarded ambulance service as insufficient. Compare these findings with another study where 54\% service providers regarded the sterilization service is good and 73\% service providers mentioned the diagnostic facilities as sufficient 6 .

Majority of the respondent's opinion regarding diagnostic facilities, essential drugs, sterilization facilities are moderately sufficient, ambulance service insufficient. Opinion regarding cost of diagnostic test is reasonable and opinion regarding infection prevention and control, physiotherapy service and housekeeping service was average.

\section{CONCLUSION}

This study the health care facilities for senior citizens during COVID-19 pandemic is provider perspective study. Older people are especially vulnerable to COVID-19. The existing healthcare services of Bangladesh will face terrible challenges due to gradual increases of ageing populations in the near future. Though the scenario lags behind that of the developed countries, various initiative need to take for the improvement of geriatric health care. According to this study findings all health care facilities are common for all patients and not sufficient for geriatric patients. In national policy making the rights of senior citizens should addressed with due respect and priority. Training for health care provider must include gerontology and geriatrics and provide opportunities to practice in care environments. Specific health care programmes for senior citizens should be formulated. Initiative should be established in geriatric department in district and medical college hospitals. To provide quality medical care for the elderly, it is necessary to establish age friendly health care facilities and unit in hospitals. There is need for change the attitude of community, government and family member. Senior citizens should not be considered as a burden to society rather their valuable experience should be utilized effectively. It is the responsibility of the government and society to ensure healthy life for senior citizens in return for their lifelong dedicated service towards their family and society.

\section{REFERENCES}

1. Islam MZ. [Lecture notes on Geriatric Health]. National Institute of Preventive and Social Medicine; notes provided at lecture given 2017 August 6.

2. Mazumder MMK. Bangladesh progress towards MIPAA implementation, Ministry of Social Welfare. Available from:

https://www.unescap.org/sites/default/files/2.\%2 0MIPAA\%20Focal\%20Point\%20Presentation1 \%20\%28Bangladesh\%29.pdf.

3. Rahman ASMA. A monthly publication of The Daily Star: [volume 3 Issue 9, October 2010]. Available from: https://archive.thedailystar.net/forum/2010/Octo ber/getting.htm.

4. Barikdar A, Ahmed T, Lasker SP. The situation of elderly in Bangladesh. Bangladesh Journal of Bioethics 2016; 7(1): 27-36. 
5. WHO. Ageing and health [Cited on 2018

February 5]. Available from:

https://www.who.int/news-room/factsheets/detail/ageing-and-health.

6. World Health Organisation Europe. Coronavirus disease (COVID-19) outbreak - Supporting older people during the COVID-19 pandemic is everyone's business 2020. Available from: http://www.euro.who.int/en/health-topics/healthemergencies/coronavirus-covid19/news/news/2020/4/supporting-older-peopleduring-the-covid-19-pandemic-is-everyonesbusiness

7. Himel MA. Management of geriatric health services in a specialized hospital 2018. 